\title{
PENGARUH SISTEM PENILAIAN KINERJA DAN KOMPENSASI TERHADAP MOTIVASI KERJA PNS
}

\author{
Raja Syafira Nurmagustini ${ }^{1}$ \\ Hajan Hidayat ${ }^{2}$ \\ Program Studi Akuntansi Manajerial, Politeknik Negeri Batam \\ Jl. Ahmad Yani, Batam Centre, Batam 29461, Indonesia \\ 1) E-mail: : rajasyafira40@gmail.com ${ }^{1}$ \\ ${ }^{2)}$ E-mail: ely@polibatam.ac.id ${ }^{2)}$
}

\begin{abstract}
Abstrak
Penelitian ini bertujuan untuk mengetahui pengaruh sistem penilaian kinerja dan kompensasi terhadap motivasi kerja pegawai negeri sipil (PNS). Motivasi sebagai variabel dependen dan variabel independen dalam penelitian ini adalah sistem penilaian kinerja dan kompensasi. Sistem penilaian kinerja bagi PNS menggunakan Sasaran Kerja Pegawai (SKP) dan perilaku kerja. Fokus penilitian ini adalah untuk mengetahui sejauh manakah pengaruh sistem penilaian kinerja dan kompensasi terhadap motivasi kerja pegawai dan untuk mengetahui sejauh mana penilaian berdasarkan SKP dan perilaku kerja yang digunakan oleh 10 instansi pemerintah di Kota Batam. Metode yang digunakan yaitu purposive sampling dan mendapatkan hasil 126 sampel staff PNS. Pengumpulan data menggunakan kuesioner yang diambil di 10 instansi pemerintah Kota Batam. Hasil dari penelitian ini adalah sistem penilaian kinerja dan kompensasi berpengaruh terhadap motivasi kinerja. Penelitian ini hanya pada 10 instansi pemerintah Kota Batam oleh karena itu penelitian selanjutnya disarankan menambahkan beberapa instansi lainnnya sehingga mempunyai jumlah sampel lebih banyak. Penelitian ini dapat dijadikan acuan untuk pemerintah dalam meningkatkan motivasi kinerja karyawan.
\end{abstract}

\begin{abstract}
This research aims to know the influence of the system of performance appraisal and compensation against the work motivation of civil servants (CIVIL SERVANTS). The motivation of the dependent variable and independent variable in this study is the system of performance appraisal and compensation. Performance assessment system for Employees Working Objectives using the PNS (SKP) and work behavior. The focus of this penilitian is to know as far as where the influence of the system of performance appraisal and compensation against the motivation of working employees and to know the extent to which the assessment is based on the working and behavior of SKP used by 10 agencies the Government in Batam city. Methods used i.e., purposive sampling of 126 sample and get the staff of CIVIL SERVANTS. Data collection using the questionnaire taken at 10 government agencies Batam city. The results of this research is the system of performance appraisal and compensation effect to performance motivation. The research on just 10 government agencies Batam city therefore recommended further research added several other establishments so as to have more sample amount. This research is referable to the Government in increasing the motivation of employee performance.
\end{abstract}




\section{Pendahuluan}

Sumber daya manusia dalam suatu organisasi adalah salah satu aspek penting yang menentukan keberhasilan organisasi. Organisasi akan mampu mencapai tujuannya apabila terdapat manusia manusia yang berkualitas dan memiliki tujuan yang searah dengan tujuan organisasi. Mathis dan Jackson (2001) mengungkapkan bahwa sumber daya manusia adalah mitra strategis, dapat disimpulkan bahwa kesuksesan organisasi sangat ditentukan oleh efektifitas kinerja semua staff/anggota organisasi, guna mecapai tujuan tersebut organisasi harus memastikan bahwa karyawan mempunyai motivasi yang tinggi. Torang (2014) menyatakan bahwa motivasi adalah energi yang menggerakkan individu untuk berusaha mencapai tujuan yang diharapkan. Menurut Robbins \&Judge (2008), motivasi sebagai proses yang menjelaskan intesitas,arah, dan ketekunan seorang individu untuk mencapai tujuannya. Motivasi dapat bersumber dari dorongan dari dalam diri maupun dari luar diri seseorang. Sistem dalam organisasi yang mempengaruhi motivasi karyawan adalah sistem penilaian kinerja \& kompensasi. Hasil penelitian yang dilakukan oleh Murdianto (2014) bahwa sistem penilaian kinerja mempengaruhi motivasi kerja, menurut Bulto \& Markos (2017) sistem penilaian kinerja terhadap motivasi menunjukkan hasil yang signifikan. Sejalan dengan penelitian yang diteliti oleh Toufanian (2012) bahwa sistem penilaian kinerja merupakan komponen penting dan motivasi sebagai alat untuk berkomunikasi kepada karyawan dan menyediakan mereka dengan umpan balik.

Menurut Desler (1996) kompensasi adalah semua bentuk penggajian atau ganjaran mengalir kepada para pegawai dan timbul dari kepegawaiannya mereka. Kompensasi langsung atau tidak langsung dalam bentuk manfaat dan insentif untuk memotivasi karyawan agar produktivitas kerja semakin meningkat/tinggi. Kompensasi dalam bentuk finansial langsung seperti gaji, upah, komisi, dan bonus sedangkan kompensasi tidak langsung seperti asuransi, bantuan sosial, uang pensiun, pendidikan dan lain lain (Yani, 2012).

Hasil penelitian menunjukkan bahwa kompensasi mempengaruhi motivasi kerja (Tufail \& Sajid, 2015). Menurut Penelitian Rizal et al. (2014) menunjukkan bahwa kompensasi memiliki efek signifikan terhadap motivasi. Aparatur pemerintah (civil service) merupakan unsur penting dalam pengelolaan suatu negara. Ia adalah sumber daya yang akan melaksanakan seluruh kebijakan yang dikeluarkan oleh suatu Negara (Wibisana, 2016). Pemerintah menetapkan sistem penilaian kinerja yang baru yang sebelumnya dikenal dengan DP3 yaitu Daftar Penilaian Pelaksanaan pekerjaan yang sekarang disebut dengan Sasaran Kerja Pegawai (SKP) yang mulai dilaksanakan pada tahun 2014. Sistem penilaian kerja diatur pada peraturan pemerintah nomor 46 tahun 2011 tentang penilain prestasi kerja Pegawai Negeri Sipil (PNS) yang dimana tujuannya untuk meningkatkan prestasi kinerja PNS.

Sistem penilaian kerja Pegawai Negeri Sipil (PNS) berdasarkan peraturan pemerintah nomor 46 tahun 2011 pasal 4 yaitu terdiri atas 2 unsur yaitu Sasaran Kerja Pegawai (SKP) dan Perilaku Kerja. Sasaran Kerja Pegawai (SKP) merupakan rencana kerja dan target yang akan dicapai oleh seorang PNS dan dilakukan berdasarkan kurun waktu tertentu sedangkan perilaku kerja merupakan setiap tingkah laku, sikap atau tindakan yang dilakukan oleh seorang PNS yang seharusnya dilakukan atau tidak dilakukan sesuai dengan ketentuan peraturan perundang undangan yang berlaku. Dengan sistem penilaian tersebut diharapkan Pegawai Negeri Sipil (PNS) memiliki kinerja yang baik. Untuk mendukung pencapaian prestasi kerja, sistem kompensasi diperlukan untuk memotivasi para pegawai agar dapat membentuk perilaku kerja yang baik hingga nantinya tercipta kinerja yang baik pula. Kompensasi atau yang biasanya disebut dengan tunjangan dalam pemerintahan ada pun hak yang diterima oleh PNS berdasarkan Undang - Undang Republik Indonesia nomor 5 tahun 2014 tentang Aparatur Sipil Negara yaitu: pasal 21 dimana PNS berhak memperoleh: a. gaji, tunjangan, dan fasilitas; b. cuti; c. jaminan pensiun dan jaminan hari tua; d. perlindungan; dan e. Pengembangan kompetensi.

Berdasarkan penelitian terdahulu oleh 
Winarni \& Ahmad (2016) bahwa penilaian kinerja berdasarkan penilaian prestasi kerja dan kompensasi berpengaruh terhadap kinerja pegawai Non-PNS, sejalan dengan penelitian Gultom, Saryadi \& Nurseto (2015) menunjukkan bahwa penilaian kerja dan kompensasi berpengaruh terhadap kinerja karyawan melalui motivasi. Pemerintah telah membuat kebijakan baru tentang sistem penilaian kinerja terhadap PNS dengan menggunakan sasaran kerja pegawai (SKP) dan perilaku kerja, dengan kebijakan tersebut sehingga penulis tertarik untuk meneliti bagaimana pengaruh sistem penilaian kinerja dan kompensasi terhadap motivasi kerja PNS.

\section{Kerangka Teori}

\subsection{Teori dan Penelitian Terdahulu}

Teori yang dikemukakan oleh Locke (1960) adalah bahwa niat untuk mencapai sebuah tujuan merupakan sumber motivasi kerja yang utama, artinya tujuan memberi tahu seorang karyawan apa yang harus dilkukan dan berapa banyak usaha yang harus dikeluarkan. Bukti tersebut sangat mendukung nilai tujuan. Kita bisa mengatakan bahwa tujuan khusus meningkatkan kinerja; tujuan yang sulit, ketika diterima, menghasilkan kinerja yang lebih tinggi dari pada tujuan yang mudah; dan umpan balik menghasilkan kinerja yang lebih tinggi dari pada tidak ada umpan balik. Teori penentuan tujuan mengisyaratkan bahwa seorang individu berkomitmen pada tujuan tersebut. Berdasarkan perilaku, ini berarti bahwa seorang individu (a) yakin ia bisa mencapai tujuan tersebut (b) ingin mencapainya (Robbins \& Judge, 2008).

Teori penguatan yang dikemukakan oleh Skinner (1904 - 1990) dan rekan - rekannya adalah teori dimana perilaku merupakan sebuah fungsi dari konsikuensi-konsikuensinya. Dalam teori penguatan ada sebuah pendekatan perilaku yang menunjukkan bahwa penguatan mempengaruhi perilaku. Teoretikus-teoretikus penguatan menganggap perilaku disebabkan oleh lingkungan, teori penguatan mengabaikan keadaaan batin individu dan hanya terpusat pada apa yang terjadi pada seseorang ketika ia melakukan tindakan (Robbins \& Judge, 2008).
Penelitian tentang pengaruh sistem penilaian kinerja terhadap motivasi menunjukkan bahwa sistem penilaian kinerja berpengaruh terhadap motivasi. Berikut hasil - hasil penelitian sistem penilaian kinerja terhadap motivasi.

Terdapat beberapa hasil penelitian terdahulu mengenai pengaruh sistem penilaian kinerja terhadap motivasi yaitu penelitian yang dilakukan oleh Murdianto (2014) terhadap variabel sistem penilaian kinerja yaitu berpengaruh terhadap motivasi kerja karyawan, hasil dari penelitian tersebut menyimpulkan bahwa sistem penilaian kerja mempunyai kategori yang baik.

penilaian kinerja pegawai pada penelitian ini dilihat berdasarkan tanggapan pegawai yang dinilai dan tanggapan atasan langsung yang bertindak sebagai penilai. Hasil penelitian menunjukkan bahwa tingkat efektivitas penilaian kinerja pegawai terdapat pengaruh yang signifikan dan positif antara variabel efektivitas penilaian kinerja terhadap motivasi kerja pegawai (Irwan, 2015).

Bulto \& Markos (2017) hasil penelitian yang diteliti menunjukkan bahwa variabel Sistem Penilaian Kinerja Terhadap Motivasi Menunjukkan Hasil Yang Signifikan, yang artinya bahwa variabel sistem penilaian kinerja berpengaruh terhadap variabel motivasi. Penelitian tentang pengaruh kompensasi terhadap motivasi menunjukkan bahwa kompensasi berpengaruh terhadap motivasi. Berikut hasil - hasil penelitian kompensasi terhadap motivasi. Adapun penelitian terdahulu yang berkaitan dengan penelitian ini yaitu Tufail \& Sajid (2015) Variabel kompensasi mempunyai hasil yang signifikan dan positif terhadap motivasi, motivasi meningkat melalui kompensasi yang memuaskan sehingga kompensasi berpengaruh terhadap motivasi. Hasil analisis penelitian menunjukkan bahwa secara simultan dan parsial variabel Kompensasi baik kompensasi Finansial, Non Finansial mempunyai pengaruh yang signifikan terhadap Motivasi Kerja sehingga kompensasi berpengauh terhadap motivasi (Alisa, Musadieq, \& Mayowan, 2016).

Sarira (2015) menunjukkan bahwa variabel kompensasi mempunyai pengaruh signifikan terhadap 
motivasi kerja Karyawan sehingga sangat berpengaruh terhadap motivasi dikarenakan kompensasi yang dikeluarkan sangatlah menunjang dalam meningkatkan motivasi.

\subsection{Hipotesis Penelitian}

$\mathrm{H}_{1}$ : Sistem penilaian kinerja berpengaruh terhadap motivasi kerja PNS

$\mathrm{H}_{2}$ : Kompensasi berpengaruh terhadap motivasi kerja PNS

\section{Metode Penelitian}

\subsection{Populasi dan Sampel}

Jenis data di dalam penelitian ini menggunakan data primer. Data primer adalah informasi yang diperoleh dari tangan pertama oleh peneliti yang berkaitan dengan variabel penelitian yang diteliti (Sekaran, 2006: 79). Sumber data dalam penelitian ini diperolah dari Pegawai Negeri Sipil (PNS). Pada penelitian ini sampel yang digunakan yaitu secara non random (non acak) atau non probability sampling yaitu Purposive Sampling, Teknik penarikan sampel ini tidak dipilih secara acak. Unsur populasi yang dipilih guna mendapatkan hasil yang akurat serta sesuai dengan hasil yang diharapkan. Kriteria data yang dipilih sebagai responden adalah Pegawai Negeri Sipil (PNS). Populasi dalam penelitian ini adalah Pegawai Negeri Sipil (PNS) Kota Batam Non Eselon / Staff yang berada di 10 instansi Pemerintah Kota Batam dengan jumlah 183 Staff PNS. Penetapan jumlah sampel ini menggunakan Rumus Slovin yaitu :

$$
n=\frac{N}{1+N e^{2}}
$$

Ket :

$n$ : jumlah sampel

$\mathrm{N}$ : jumlah populasi

e: batas toleransi kesalahan (error tolerance)

Peneliti menggunakan penelitian dengan batas kesalahan 5\% dari populasi sehingga jumlah sampel yang didapatkan sebagai berikut:

$$
\begin{aligned}
& \mathrm{n}=183 /\left(1+183 \cdot(5 \%)^{2}\right) \\
& \mathrm{n}=183 /\left(1+183 \cdot(0,05)^{2}\right) \\
& \mathrm{n}=183 /(1+183 \cdot(0,0025)) \\
& \mathrm{n}=183 /(1+0,4575) \\
& \mathrm{n}=183 / 1,4575 \\
& \mathrm{n}=125,557 \Rightarrow \text { dibulatkan menjadi } 126 \\
& \text { orang. }
\end{aligned}
$$

Jadi, jumlah minimal sampel yang digunakan dalam penelitian ini yaitu 126 .

\subsection{Metode Analisis Data}

Data hasil survei kuesioner terhadap 10 instansi pemerintah Kota Batam dengan 126 responden di cek sesuai dengan kriteria sampel. Setelah dilakukan pengecekan data, maka selanjutnya data yang diperolah dari responden dengan total 126 responden dimasukkan kedalam microsoft excel. Setelah itu, memasukkan rumus yang telah ditetapkan dalam operasional variabel ke microsoft excel lalu melakukan olah data menggunakan SPSS 20. ini teknik pengolahan data menggunakan SPSS 20. Analisi data awal menggunakan analisis statistik deskriptif Statistik deskriptif adalah suatu metode yang berkaitan dengan pengumpulan dan penyajian sauatu data, analisis deskriptif memberikan gambaran atau deskripsi suatu data yang dilihat dari nilai rata-rata (mean), standar deviasi, varian, maksimum, minimum, sum dan range untuk variabel yang digunakan yaitu Sistem Penilaian Kinerja, Kompensasi, Motivasi. Kemudian melakukan uji instrumen yaitu uji validitas dan uji reliabilitas, banyak penelitian yang menggunakan kuesioner sebagai skala pengukuran variabel penelitian. Kriteria kuesioner yang baik salah satunya memenuhi validitas dan reliabilitas.

Uji validitas yaitu untuk mengukur sah atau valid tidaknya suatukuesioner. Suatu kuesioner dikatakan valid jika pernyataan kuesioner mampu mengungkapkan sesuatu yang akan diukur oleh kuesioner tersebut (Ghozali,2011). Validitas dalam penelitian menyatakan derajat ketepatan alat ukur penelitian terhadap isi atau arti sebenarnya yang 
diukur. Uji signifikansi dilakukan dengan membandingkan nilai rhitung dengan rtabel, jika rhitung $>$ rtabel maka variabel tersebut dinyatakan valid, begitu sebaliknya(Ghozali, 2011).

Uji Reliabilitas yaitu suatu angka indeks yang menunjukkan konsistensi suatu alat pengukur di dalam mengukur gejala yang sama. Setiap alat pengukur seharusnya memiliki kemampuan untukmemberikan hasil pengukuran yang konsisten. Reliabilitas memusatkan perhatian pada masalah konsistensi sedang yang kedua lebih memperhatikan masalah ketepatan. Instrumen yang reliabel adalah instrumen yang bilamana dicobakan secara berulang-ulang pada kelompok yang sama akan menghasilkan data yang sama akan menghasilkan data yang sama dengan asumsi tidak terdapat perubahan

psikologis terhadap responden. Secara prinsip reliabilitas mencerminkan konsistensi suatu pengukuran.Reliabilitas yang tinggi menunjukkan bahwa indikator - indikator mempunyai konsistensi yang tinggi dalam mengukur variabel latennya. Pengukuran reliabilitas dilakukan dengan uji statistik Cronbach Alpha. Suatu variabel dikatakan reliabel apabila memberikan nilai Cronbach Alpha $>0,60$ (Ghozali, 2011).

Uji asumsi klasik adalah pengujian data dalam penelitian untuk mengetahui kondisi data yang di gunakan dalam suatu penelitian. Beberapa pengujian yang harus dilakukan dalam penelitian ini adalah uji normalitas dan uji Hipotesis.

Uji normalitas yaitu untuk melihat apakah nilai residual terdistribusi normal atau tidak. Model regresi yang baik adalah memiliki nilai residual yang terdistribusi normal, sehingga uji normalitas bukan dilakukan pada masing-masing variabel tetapi pada nilai residualnya. Uji normalitas bertujuan untuk menguji salah satu asumsi dasar analisis regresi berganda, yaitu variabel - variabel independen dan dependen harus berdistribusi normal atau mendekati normal (Ghozali, 2011).

Penelitian ini menggunakan pengujian hipotesis dengan analisis regresi linier sederhana, analisis regresi sebagai suatu analisis tentang ketergantungan suatu variabel kepada variabel lain yaitu variabel bebas dalam rangka membuat estimasi atau prediksi dari nilai rata-rata variabel tergantung dengan diketahuinya nilai variabel. (Basuki \& Prawoto, 2016).

\section{Hasil}

\subsection{Karakteristik Data}

Karakteristik data pada penelitian ini dapat dilihat pada table 4.1 dibawah ini:

Tabel 4.1 Karakteristik Data

\begin{tabular}{l|c}
\hline \multicolumn{1}{c|}{ Keterangan } & Jumlah \\
\hline Kuesioner yang disebarkan & 183 \\
\hline Kuesioner yang tidak kembali & 38 \\
\hline Kuesioner yang kembali & 145 \\
\hline Total sampel yang digunakan & $\mathbf{1 2 6}$ \\
\hline $\begin{array}{l}\text { Sumber: Data diolah sendiri } \\
\text { Berdasarkan tabel 4.1 dari } 183 \text { kuesioner }\end{array}$
\end{tabular}

yang dibagikan, kuesioner kembali berjumlah 145.Kuesioner yang tidak kembali berjumlah 38 . Namun dari hasil penetapan sampel sebesar 126, peneliti mendapatkan kuesioner sejumlah sampel atau responden yang telah ditetapkan.

Tabel 4.2 Karakteristik Umum Responden

\begin{tabular}{|c|c|c|c|}
\hline \multicolumn{2}{|c|}{ Keterangan } & \multirow{2}{*}{$\begin{array}{c}\begin{array}{c}\text { Frekue } \\
\text { nsi }\end{array} \\
69 \\
\end{array}$} & \multirow{2}{*}{$\begin{array}{r}\begin{array}{r}\text { Perse } \\
\text { ntase } \\
(\%)\end{array} \\
54,8 \\
\end{array}$} \\
\hline Jenis & $\mathbf{L}$ & & \\
\hline Kelamin & $\mathbf{P}$ & 59 & 46,8 \\
\hline \multirow[t]{5}{*}{ Pendidikan } & $\begin{array}{l}\text { SMA/ } \\
\text { Sedrajat }\end{array}$ & 13 & 10,3 \\
\hline & D1-D3 & 11 & 8,7 \\
\hline & S1 & 94 & 74,6 \\
\hline & S2 & 8 & 6,3 \\
\hline & S3 & 0 & 0 \\
\hline \multirow{3}{*}{ Tahun Lahir } & $1946-1960$ & 0 & 0 \\
\hline & 1961-1980 & 96 & 76,2 \\
\hline & 1981-1995 & 30 & 23,8 \\
\hline \multirow{4}{*}{ Lama Bekerja } & 1-5 tahun & 17 & 13,5 \\
\hline & 6-10 tahun & 59 & 46,8 \\
\hline & 11-15 tahun & 42 & 33,3 \\
\hline & $>15$ tahun & 8 & 6,3 \\
\hline \multicolumn{2}{|c|}{ Jumlah Sampel } & 126 & 100 \\
\hline
\end{tabular}


Berdasarkan tabel 4.2 diperoleh informasi bahwa responden berjenis kelamin laki-laki berjumlah 69 responden dengan presentase $54,8 \%$, responden dengan jenis kelamin laki-laki dalam penelitian ini lebih banyak dibandingkan dengan perempuan berjumlah 59 responden dengan persentase sebesar $46,8 \%$. Jumlah responden dengan pendidikan terakhir S1 memiliki jumlah yang paling banyak sebesar 94 responden dengan presentase sebesar $74,6 \%$. Tahun lahir responden paling banyak ada diantara tahun 1961-1980 dengan persentase sebesar 76,2\% dibandingkan dengan usia lainnya. Untuk waktu lama bekerja responden sebagai pegawai negeri sipil (PNS) paling banyak sudah melewati selama 6-10 tahun dilihat dari besarnya persentase yaitu $46,8 \%$.

\subsection{Statistik Deskriptif}

Penyajian statistik deskriptif bertujuan untuk menggambarkan data penelitian per variabel. Berikut adalah pernyataan kuesioner yang telah diajukan kepada responden diperoleh berbagai macam tanggapan. Berbagai tanggapan dari responden tersebut dapat disajikan sebagai berikut :

\begin{tabular}{c|c|c|c|c|c|c|c|c|c}
\hline \multicolumn{7}{c}{ Jawaban Responden Frekuensi } & \multirow{2}{*}{ Total } \\
\hline \multirow{2}{*}{ Item } & \multicolumn{7}{|c}{ Motivasi } \\
\cline { 2 - 9 } & STS & \% & TS & $\%$ & S & $\%$ & SS & $\%$ & \\
\hline Y.1 & 0 & 0 & 4 & 3,2 & 78 & 61,9 & 44 & 34,9 & 126 \\
\hline Y.2 & 0 & 0 & 1 & 0,8 & 81 & 64,3 & 44 & 34,9 & 126 \\
\hline Y.3 & 0 & 0 & 0 & 0 & 80 & 63,5 & 46 & 36,5 & 126 \\
\hline Y.4 & 0 & 0 & 0 & 0 & 94 & 74,6 & 32 & 25,4 & 126 \\
\hline Y.5 & 0 & 0 & 1 & 0,8 & 96 & 76,2 & 29 & 23 & 126 \\
\hline Y.6 & 0 & 0 & 0 & 0 & 88 & 69,8 & 38 & 30,2 & 126 \\
\hline Y.7 & 0 & 0 & 0 & 0 & 92 & 73 & 34 & 27 & 126 \\
\hline Y.8 & 0 & 0 & 2 & 1,6 & 83 & 65,9 & 41 & 32,5 & 126 \\
\hline Y.9 & 0 & 0 & 0 & 0 & 83 & 65,9 & 43 & 34,1 & 126 \\
\hline Y.10 & 0 & 0 & 3 & 2,4 & 94 & 74,6 & 29 & 23 & 126 \\
\hline S
\end{tabular}

Sumber : diolah sendiri

Berdasarkan tabel 4.3, variabel motivasi menghasilkan kinerja yang berkualitas serta target yang diterapkan tercapai dengan 10 pernyataan. Dapat diketahui bahwa secara umumpara responden cenderung memilih setuju dan sangat setuju dengan pertanyaan-pertanyaan mengenai motivasi. Hal ini menunjukkan bahwa motivasi ini sangat berpengaruh besar terhadap responden.
Tabel 4.4 Distribusi Frekuensi Jawaban Responden Terhadap Variabel Sistem Penilaian Kinerja

\begin{tabular}{|c|c|c|c|c|c|c|c|c|c|}
\hline \multicolumn{10}{|c|}{ Sistem Penilaian Kinerja } \\
\hline \multirow[b]{2}{*}{ Item } & \multicolumn{8}{|c|}{ Frekuensi Jawaban Responden } & \multirow[b]{2}{*}{ Total } \\
\hline & STS & $\%$ & TS & $\%$ & $\mathbf{S}$ & $\%$ & SS & $\%$ & \\
\hline $\mathbf{X 1 . 1}$ & 0 & 0 & 0 & 0 & 80 & 63,5 & 46 & 36,5 & 126 \\
\hline $\mathbf{X 1 . 2}$ & 0 & 0 & 0 & 0 & 76 & 60,3 & 50 & 39,7 & 126 \\
\hline $\mathbf{X 1 . 3}$ & 0 & 0 & 0 & 0 & 78 & 61,9 & 48 & 38,1 & 126 \\
\hline X1.4 & 0 & 0 & 1 & 0,8 & 82 & 65,1 & 43 & 34,1 & 126 \\
\hline $\mathbf{X 1 . 5}$ & 0 & 0 & 1 & 0,8 & 85 & 67,5 & 40 & 31,7 & 126 \\
\hline X1.6 & 1 & 0,8 & 2 & 1,6 & 81 & 64,3 & 42 & 33,3 & 126 \\
\hline X1.7 & 0 & 0 & 2 & 1,6 & 80 & 63,5 & 44 & 34,9 & 126 \\
\hline $\mathbf{X 1 . 8}$ & 0 & $\overline{0}$ & 5 & 4 & 77 & 61,1 & 44 & 34,9 & 126 \\
\hline X1.9 & 0 & 0 & 0 & 0 & 90 & 71,4 & 36 & 28,6 & 126 \\
\hline $\mathbf{X} 1.10$ & 0 & 0 & 0 & 0 & 87 & 69 & 39 & 31 & 126 \\
\hline X1.11 & 0 & 0 & 3 & 2,4 & 79 & 62,7 & 44 & 34,9 & 126 \\
\hline 1.12 & 0 & 0 & 1 & 0,8 & 89 & 70,6 & 36 & 28,6 & 126 \\
\hline $\mathbf{X 1 . 1 3}$ & 0 & 0 & 4 & 3,2 & 86 & 68,3 & 36 & 28,6 & 126 \\
\hline $\mathbf{X} 1.14$ & 0 & 0 & 0 & 0 & 89 & 70,6 & 37 & 29,4 & 126 \\
\hline X1.15 & 0 & c & 3 & 2,4 & 92 & 73 & 31 & 24,6 & 126 \\
\hline $\mathbf{X} 1.16$ & 0 & 0 & 1 & 0,8 & 91 & 72,2 & 34 & 27 & 126 \\
\hline $\mathbf{X} 1.17$ & 1 & 0,8 & 1 & 0,8 & 80 & 63,5 & 44 & 34,9 & 126 \\
\hline $\mathrm{X} 1.18$ & 0 & $\overline{0}$ & 1 & 0,8 & 88 & 69,8 & 37 & 29,4 & 126 \\
\hline $\mathbf{X 1 . 1 9}$ & 0 & 0 & 2 & 1,6 & 81 & 64,3 & 43 & 34,1 & 126 \\
\hline $\mathbf{X} 1.20$ & 0 & 0 & 2 & 1,6 & 86 & 68,3 & 38 & 30,2 & 126 \\
\hline $\mathbf{X} 1.21$ & 0 & 0 & 2 & 1,6 & 71 & 56,3 & 53 & 42,1 & 126 \\
\hline $\mathbf{X 1 . 2 2}$ & 0 & 0 & 2 & 1,6 & 98 & 77,8 & 26 & 20,6 & 126 \\
\hline $\mathbf{X} 1.23$ & 0 & 0 & 2 & 1,6 & 91 & 72,2 & 33 & 26,2 & 126 \\
\hline $\mathbf{X} 1.24$ & 0 & 0 & 1 & 0,8 & 71 & 56,3 & 54 & 42,9 & 126 \\
\hline
\end{tabular}

Sumber : diolah sendiri

Berdasarkan hasil tabel 4.4 variabel Sistem penilaian kinerja diukur menggunakan 24 pernyataan. Tanggapan respoden sebagaimana pada tabel 4.4 menunjukkan bahwasebagian besar responden memberikan tanggapan setuju dan sangat setuju terhadap variabel sistem penilaian kinerja, namun ada beberapa responden yang memilih tidak setuju.Hal ini menunjukkan bahwa sebagian besar pegawai negeri sipil (PNS)sangat setuju terhadap sistem penilaian kinerja sebagai alat ukur yang sangat berpengaruh terhadap motivasi. 
Tabel 4.5 Distribusi Frekuensi Jawaban

\section{Responde Terhadap Variabel}

Kompensasi

\section{Kompensasi}

\begin{tabular}{c|c|c|c|c|c|c|c|c|c}
\hline \multirow{2}{*}{ Item } & \multicolumn{7}{|c|}{ Frekuensi Jawaban Responden } & \multirow{2}{*}{ Total } \\
\cline { 2 - 9 } & STS & $\%$ & TS & $\%$ & S & $\%$ & SS & $\%$ & \\
\hline X2.1 & 0 & 0 & 5 & 4 & 84 & 66,7 & 37 & 29,4 & 126 \\
\hline $\mathbf{X 2 . 2}$ & 0 & 0 & 2 & 1,6 & 80 & 63,5 & 44 & 34,9 & 126 \\
\hline $\mathbf{X 2 . 3}$ & 0 & 0 & 3 & 2,4 & 86 & 68,3 & 37 & 29,4 & 126 \\
\hline $\mathbf{X 2 . 4}$ & 0 & 0 & 5 & 4 & 78 & 61,9 & 43 & 34,1 & 126 \\
\hline $\mathbf{X 2 . 5}$ & 0 & 0 & 0 & 0 & 82 & 65,1 & 44 & 34,9 & 126 \\
\hline $\mathbf{X 2 . 6}$ & 0 & 0 & 3 & 2,4 & 70 & 55,6 & 53 & 42,1 & 126 \\
\hline
\end{tabular}

Berdasarkan tabel 4.5 variabel kompensasi menghasilkan motivasi yang tinggi serta target yang diterapkan tercapai dengan 6 pernyataan. Dapat diketahui bahwa secara umum responden dengan adanya upah tambahan atau tunjangan pekerjaan yang dilakukan kinerja kerja akan lebih baik. Hal ini tercermin dari jawaban responden yang cenderung setuju dan sangat setuju meskipun ada beberapa yang tidak setuju dengan pernyataan tersebut.

\subsection{Pengujian Instrumen}

\subsubsection{Uji Validitas}

Uji validitas yaitu untuk mengukur sah atau valid tidaknya suatu kuesioner. Suatu kuesioner dikatakan valid jika pernyataan kuesioner mampu mengungkapkan sesuatu yang akan diukur oleh kuesioner tersebut (Ghozali,2011). Uji ini diperlukan guna mendapatkan ketetapan hasil apakah kuesioner yang akan dibagikan kepada responden dapat dimengerti atau tidak, serta mampu mengungkapkan hasil yang diukur. Berikut dapat dilihat pada tabel 4.6

Tabel 4.6 Hasil Uji Validitas Variabel Motivasi

\begin{tabular}{c|c|c|c}
\hline $\begin{array}{c}\text { Variabel } \\
\text { Motivasi }\end{array}$ & r hitung & r tabel & Kesimpulan \\
\hline Q1 & 0,375 & & Valid \\
\hline Q2 & 0,366 & & Valid \\
\hline Q3 & 0,383 & & Valid \\
\hline Q4 & 0,463 & & Valid \\
\hline Q5 & 0,467 & $\mathbf{0 , 1 7 3}$ & Valid \\
\hline Q6 & 0,454 & & Valid \\
\hline Q7 & 0,480 & & Valid \\
\hline Q8 & 0,424 & & Valid \\
\hline Q9 & 0,515 & & Valid \\
\hline Q10 & 0,343 & & Valid \\
\hline
\end{tabular}

Sumber : Hasil Output SPSS 20.
Berdasarkan hasil uji validitas variabel motivasi dengan kuesioner yang dilakukan pada 126 responden,diketahui bahwa masing - masing indikator pertanyaan yang digunakan oleh peneliti mempunyai $r$ hitung $>\mathrm{r}$ tabel, yang artinya indikator pertanyaan dari variable motivasi yang peneliti gunakan dalam penelitian ini adalah valid untuk digunakan sebagai alat ukur variabel.

\section{Tabel 4.7 Hasil Uji Validitas Variabel Sistem}

\section{Penilaian Kinerja}

\begin{tabular}{|c|c|c|c|}
\hline $\begin{array}{l}\text { Variabel } \\
\text { Sistem } \\
\text { Penilaian } \\
\text { Kinerja }\end{array}$ & $\mathrm{r}$ hitung & $r$ tabel & Kesimpulan \\
\hline Q1 & 0,285 & & Valid \\
\hline Q2 & 0,455 & & Valid \\
\hline Q3 & 0,499 & & Valid \\
\hline Q4 & 0,412 & & Valid \\
\hline Q5 & 0,332 & & Valid \\
\hline Q6 & 0.380 & & Valid \\
\hline Q7 & 0.420 & & Valid \\
\hline $\mathrm{Q} 8$ & 0,401 & & Valid \\
\hline Q9 & 0,430 & & Valid \\
\hline Q10 & 0,403 & & Valid \\
\hline Q11 & 0,383 & \multirow[b]{2}{*}{0,173} & Valid \\
\hline Q12 & 0.438 & & Valid \\
\hline Q13 & 0.261 & & Valid \\
\hline Q14 & 0,307 & & Valid \\
\hline Q15 & 0,363 & & Valid \\
\hline Q16 & 0,262 & & Valid \\
\hline Q17 & 0,369 & & Valid \\
\hline Q18 & 0,328 & & Valid \\
\hline Q19 & 0,305 & & Valid \\
\hline Q20 & 0,386 & & Valid \\
\hline Q21 & 0,242 & & Valid \\
\hline Q22 & 0,233 & & Valid \\
\hline Q23 & 0,312 & & Valid \\
\hline Q24 & 0,220 & & Valid \\
\hline
\end{tabular}

Sumber : Hasil Output SPSS 20.

Berdasarkan hasil uji validitas variabel sistem penilaian kinerja dengan menggunakan kuesioner yang dilakukan pada 126 responden,diketahui bahwa masing-masing indicator pertanyaan yang digunakan oleh peneliti mempunyai $\mathrm{r}$ hitung $>\mathrm{r}$ tabel, yang artinya indikator pertanyaan dari variabel sistem penilaian kinerja yang peneliti gunakan dalam penelitian ini adalah valid untuk digunakan sebagai alat ukur variable 
Tabel 4.8 Hasil Uji Validitas Variabel

\section{Kompensasi}

\begin{tabular}{c|c|c|c}
\hline $\begin{array}{c}\text { Variabel } \\
\text { Kompensasi }\end{array}$ & r hitung & r tabel & Kesimpulan \\
\hline Q1 & 0,447 & & Valid \\
\hline Q2 & 0,454 & & Valid \\
\hline Q3 & 0,503 & $\mathbf{0 , 1 7 3}$ & Valid \\
\hline Q4 & 0,525 & & Valid \\
\hline Q5 & 0,482 & & Valid \\
\hline Q6 & 0,668 & & Valid \\
\hline
\end{tabular}

Sumber : Hasil Output SPSS 20.

Berdasarkan hasil uji validitas variabel kompensasi dengan menggunakan kuesioner yang dilakukan pada 126 responden, diketahui bahwa masing masing indikator pertanyaan yang digunakan oleh peneliti mempunyai $r$ hitung $>r$ tabel, yang artinya indikator pertanyaan dari variabel kompensasi yang peneliti gunakan dalam penelitian ini adalah valid untuk digunakan sebagai alat ukur variabel.

\subsubsection{Uji Reliabilitas}

Pengukuran reliabilitas dilakukan dengan uji statistik Cronbach Alpha. Suatu variabel dikatakan reliabel apabila memberikan nilai Cronbach Alpha $>0,60$ (Ghozali, 2011).

\section{Tabel 4.9 Uji Reliabilitas}

\begin{tabular}{l|c|c}
\hline Keterangan & $\begin{array}{c}\text { Cronbach's } \\
\text { Alpha }\end{array}$ & Kesimpulan \\
\hline Motivasi & 0,672 & Reliabel \\
\hline $\begin{array}{l}\text { Sistem Penilaian } \\
\text { Kinerja }\end{array}$ & 0,693 & Reliabel \\
\hline Kompensasi & 0,691 & Reliabel
\end{tabular}

Sumber : Hasil Output SPSS 20.

Berdasarkan hasil uji realibilitas pada tabel 4.9 maka dapat disimpulkan bahwa kuesioner yang digunakan dalam peneliti sudah dikatakan reliabel karena nilai Cronbach's Alpha dari masing-masing variabel lebih besar dari 0,60 .

\subsection{Uji Asumsi Klasik \\ 4.4.1 Uji Normalitas}

\section{Tabel 4.10 Hasil Uji Normalitas}

\begin{tabular}{l|c}
\hline \multicolumn{2}{c}{ Unstandardized Residual } \\
\hline $\mathbf{N}$ & 126 \\
Kolmogorov-Smirnov Z & 0,956 \\
Asymp. Sig. (2-tailed) & 0,321 \\
\hline
\end{tabular}

Sumber : Hasil Output SPSS 20.

Berdasarkan tabel 4.10, besarnya Kolmogorov-Smirnov nilai adalah 0,956 dan nilai signifikansinya adalah 0,321. Nilai signifikansi tersebut lebih besar dari 0,05, sehingga dapat disimpulkan bahwa data residual telah berdistribusi normal.

\subsection{Pengujian Hipotesis}

Metode yang penulis gunakan dalam melakukan uji hipotesis didalam penelitian ini adalah regresi linear sederhana dengan uji signifikansi. Hipotesis pertama dan hipotesis kedua yang diajukan dalam penelitian ini menyatakan bahwa sistem penilaian kinerja berpengaruh terhadap motivasi kerja PNS, kompensasi berpengaruh terhadap motivasi kerja PNS. Hipotesis ini dapat didukung apabila nilai signifikansinya menunjukan nilai $<0.05$ dan tidak dapat didukung jika sebaliknya. Hasil uji signifikansi model persamaan pertama dan kedua dalam penelitian ini dapat dilihat pada berikut :

Tabel 4.11 Hasil Uji Hipotesis Pertama (H1)

\begin{tabular}{|c|c|c|c|c|}
\hline Variabel & B & $\begin{array}{l}\text { Standar } \\
\text { Eror }\end{array}$ & $\begin{array}{l}\text { t-hitu } \\
\text { ng }\end{array}$ & $\begin{array}{l}\text { Sig } \\
\text {. }\end{array}$ \\
\hline Konstanta & $\begin{array}{l}9.84 \\
7\end{array}$ & 2.144 & 4.593 & $\begin{array}{c}0.0 \\
00\end{array}$ \\
\hline $\begin{array}{l}\text { Sistem } \\
\text { Penilaian } \\
\text { Kinerja }\end{array}$ & $\begin{array}{l}0.30 \\
6\end{array}$ & 0.065 & 4.708 & $\begin{array}{l}0.0 \\
00\end{array}$ \\
\hline R-Square & & & 0.152 & \\
\hline $\begin{array}{l}\text { Adjusted } \\
\text { R-Square }\end{array}$ & & & 0.145 & \\
\hline Sumber: & $\begin{array}{l}\text { sil Ou } \\
=\alpha+ \\
=9.8\end{array}$ & $\begin{array}{l}\text { ut SPSS } 20 \\
1 \mathrm{SPK}_{\mathrm{it}}+8 \\
+0.306 \mathrm{SP}\end{array}$ & & \\
\hline
\end{tabular}

Berdasarkan tabel 4.11 menunjukkan bahwa variabel 
sistem penilaian kinerja memiliki nilai signifikansi sebesar 0,000 ini membuktikan bahwa nilai signifikansi lebih kecil dai 0.05 yang artinya $\mathrm{H} 1$ dapat terdukung. Definisi dari persamaan regresi diatas tersebut adalahkonstanta sebesar9.847 akanmeningkat sebesar koefisien regresi sistem penilaian kinerja yaitu 0.306.Koefisien determinasi (Adjusted $R^{2}$ ) sebesar 0.145 , hal ini berarti hanya $14,5 \%$ variabel dependen yaitu motivasi dapat dijelaskan oleh variabel independen yaitu sistem penilaian kinerja. Sisanya $(100 \%-14,5 \%=85,5 \%)$ dijelaskan oleh variabel lain.

Tabel 4.12 Hasil Pengujian Hipotesis (H2)

\begin{tabular}{llccc}
\hline Variabel & B & Standar Eror & $\begin{array}{l}\text { t-hitu } \\
\text { ng }\end{array}$ & Sig. \\
\hline Konstanta & $\begin{array}{l}8.19 \\
3\end{array}$ & 2.542 & 3.223 & $\begin{array}{c}0.00 \\
2\end{array}$ \\
Kompensasi & $\begin{array}{l}0.14 \\
8\end{array}$ & 0.032 & 4.620 & $\begin{array}{c}0.00 \\
0\end{array}$ \\
\hline $\begin{array}{l}\text { R-Square } \\
\text { Adjusted }\end{array}$ & & & 0.147 & \\
R-Square & & & 0.140 & \\
\hline
\end{tabular}

Sumber : Hasil Output SPSS 20.

$$
\begin{gathered}
\mathrm{M}=\alpha+\beta 1 \mathrm{KOM}_{\mathrm{it}}+\varepsilon \ldots \mathrm{H} 2 \\
\mathrm{M}=8.193+0.148+\varepsilon
\end{gathered}
$$

Berdasarkan tabel 4.12 menunjukkan bahwa variabel kompensasi memiliki nilai signifikansi sebesar 0,000 yang artinya $\mathrm{H} 2$ terdukung. ini membuktikan bahwa nilai signifikansi lebih kecil dari 0.05 . Definisi dari persamaan regresi diatas tersebut adalah konstanta sebesar 8.193 akan meningkat sebesar koefisien regresi kompensasi yaitu 0.148. Koefisien determinasi (Adjusted $R^{2}$ ) sebesar 0.140, hal ini berarti hanya 14\% variabel dependen yaitu motivasi dapat dijelaskan oleh variabel independen yaitu kompensasi. Sisanya (100\% $-14 \%=86 \%$ ) dijelaskan oleh variabel lain.

Tabel 4.13 Ringkasan Hasil Uji Hipotesis

\begin{tabular}{ll}
\hline Hipotesis & Simpulan \\
\hline H1: Pengaruh sistem penilaian & Terdukung \\
kinerja terhadap motivasi & \\
kerja PNS & \\
H2: Pengaruh kompensasi & Terdukung \\
terhadap motivasi kerja PNS & \\
\hline
\end{tabular}

Sumber : diolah sendiri

\section{Kesimpulan}

Berdasarkan hasil penelitian diatas mengenai pengaruh sistem penilaian kinerja dan kompensasi terhadap motivasi kerja PNS, dapat diambil kesimpulan sebagai berikut ini:

- Hasil pengujian menunjukkan bahwa sistem penilaian kinerja berpengaruh terhadap motivasi kerja PNS. Hasil tersebut menunjukkan bahwa sistem penilaian kinerja yang digunakan oleh PNS benar - benar dijadikan tolak ukur dan umpan balik bagi PNS itu sendiri dan pemerintah Kota Batam dalam meningkatkan kualitas kinerja kerja PNS sehingga menjadikan sistem penilaian kinerja sebagai motivasi bagi PNS itu sendiri.

Hasil pengujian menunjukkan bahwa kompensasi berpengaruh terhadap motivasi kerja PNS. Hasil tersebut menunjukkan bahwa kompensasi yang diterima oleh PNS Kota Batam selama ini sangat baik dan mencukupi sehingga kompensasi memotivasi PNS untuk terus bekerja dengan lebih baik lagi.

\section{Saran dan Keterbatasan}

Dari hasil penelitian yang dilakukan, penting bagi atasan untuk selalu memperhatikan sistem penilaian kinerja pegawai negeri sipil (PNS) di Kota Batam, mengingat bahwa sistem penilaian kinerja berdasarkan sasaran kerja pegawai (SKP) masih terbilang sangat baru digunakan pada tahun 2014 dan atasan juga harus memberikan penghargaan, upah, promosi dan faktor pendukung lainnnya terhadap pekerjaan yang mereka jalani sehingga memberikan dorongan yang memenuhi kinerja dan umpan balik karyawan, Sehingga nantinya dapat mempengaruhi motivasi karyawan secara positif guna meningkatkan kinerja dan mengetahui keadaan lingkungan kerja. Selanjutnya penelitianini dapat dilakukan untuk sampel atau lokasi lain, dan dapat melakukan pengembangan variabel lain yang berpengaruh terhadap motivasi kerja.

Penelitian ini hanya menggunakan kuesioner dalam pengumpulan data yang memungkinkan data yang diperoleh tidak sama, karena perbedaan keseriusan responden dalam 
mengisi kuesioner. Penelitian ini tidak menggunakan teknik wawancara dalam pengumpulan data, sehingga hasil dan kesimpulan hanya didapat berdasarkan kuesioner. Peneliti hanya membahas secara singkat tidak mendalam mengenai motivasi.

\section{Daftar Pustaka}

[1] Alisa, F. A., Musadieq, M. A., \& Mayowan, Y. (2016). Pengaruh Kompensasi KerjaDan LingkunganKerja Terhadap Motivasi Kerja (Studi Pada Karyawan PT Bri Syariah Kantor Cabang Malang). Jurnal Administrasi Bisnis, 32.

[2] Ayudhia, D. K. (2008). Analisis Hubungan Sistem Penilaian Kinerja Dan Kepuasan Kerja Karyawan (Studi Kasus: Karyawan Pt. X Tbk. Bogor).

[3] Basuki, A. T., \& Prawoto, N. (2016). Analisis Regresi Dalam Penelitian Ekonomi \&Bisnis (Dilengkapi Aplikasi Spss \& Eviews ). Jakarta: PT Raja grafindo Persada.

[4] Bulto, L., \& Markos, S. (2017). Effect Of Performance Appraisal System On. Prestige International Journal of Management \& It-Shancayan, 6 (2), 25-36.

[5] Gultom, C. N., Saryadi, \& Nurseto, S. (2015). Pengaruh Penilaian Kinerja, Kompensasi, Motivasi terhadap Kinerja Karyawan melalui Motovasi pada PT. Bank Negara Indonesia (Persero) Tbk. Cabang UNDIP Semarang.

[6] Indah Puji Hartatik, S. M. (2014). Buku Praktis Mengembangkan Sdm. (V. P.Nareswati,Penyunt.) Jogjakarta: Laksana.
[7] Irwan, D. (2015). Analisis Pengaruh Efektivitas Penilaian Kinerja Pegawai Terhadap Motivasi Kerja Pegawai Pada Kantor Perwakilan Pemerintah Provinsi Gorontalo Di Jakarta 5 .

[8] Jaya, B. T. (2015). Pengaruh Moderasi Motivasi Pada Hubungan Kompensasi Terhadap Kinerja.

[9] Kurnia, R. J. (2016). Pengaruh Kompensasi Dan Motivasi Kerja Terhadap Kinerja

Karyawan Rumah Sakit Condong Catur Yogyakarta.

[10] Murdianto, A. M. (2014). Pengaruh Sistem Penilaian Kerja Terhadap Motivasi Karyawan Kantor Pusat PT Infomedia Nusantara Di Jakarta . E-Proceeding Of Management, 15-25.

[11] Peraturan Pemerintah Republik Indonesia Nomor 46 Tahun 2011 (Penilaian Prestasi Kerja Pegawai Negeri Sipil ).

[12] Priyono. (2010). Manajeman Sumberdaya Manusia. Surabaya: Zifatama.

[13] Priyono, \& Marnis. (2008). Manajeman Sumber Daya Manusia. (T. Chandra) Surabaya: Zifatama.

[14] Prof.Dr.H.Imam Ghozali, M. A. (2011). Aplikasi Analisis Multivariate Dengan Program SPSS. Semarang.

[15] Purwaningrum, E. L., Musadieq, M. A., \& Ruhana, I. (2014). Pengaruh Penilaian Kinerja Terhadap Semangat Kerja (Studi Pada Karyawan Tetap PT. Aggiomultimex). Jurnal Administrasi Bisnis (Jab), Vol. 8 No.2, 1-10. 
[16] Rakhman, M. N. (2016). Pengaruh Penilaian Kinerja Dan Motivasi Terhadap Produktivitas Pegawai Badan Kepegawaian Daerah Provinsi Lampung.

[17] Rizal, M., Idrus, M. S., Djumahir, \& Mintari, R. (2014). Effect of Compensation on Motivation, Organizational Commitment and Employee Performance (Studies at Local Revenue Managemant in Kendari City). Business Management Invention, 3 (2), 64-79.

[18] Robbins, S. P., \& A.Judge, T. (2008). Perilaku Organisasi, Edisi 12 BUKU 1. Jakarta: Salemba Empat.

[19] Saputri, L. T., Fudholi, A., \& Sumarni. (2014). Effect Of Work Motivation And Organization Culture On Employee. Manajemen Dan Pelayanan Farmasi, 4 (01), 63-68.

[20] Sarira, N. B. (2015). Pengaruh Kompensasi Terhadap Motivasi Kerja PT. Insani Baraperkasa. Ilmu Administrasi Bisnis .

[21] Torang, D. S. (2014). Organisasi \& Manajeman (Perilaku, Struktur, Budaya \& Perubahan Organisasi ). Bandung: Alfabeta.

[22] Toufanian, B. (2012). The Study Of The Employees' Performance Appraisal System At Imam-Khomeini Relief Foundation. International Journal Of Arts \& Sciences , 11-18.

[23] Tufail, S., \& Sajid, M. (2015). An Empirical Study of Relationship between Compensation,

[24] Working Environment and Motivation of Employees in Banking Sector of Pakistan. Marketing and Consumer Research, 6.
[25] Undang Undang Republik Indonesia Nomor 5

Tahun 2014 (Tentang Aparatur Sipil Negara).

[26] Vortuna, B. V. (2016). Pengaruh Penilaian Kinerja dan Kompensasi terhadap Motivasi Kerja Karyawan (Studi pada karyawan tetap Pg. Krebet Baru Malang). Ilmiah Mahasiswa Fakultas Ekonomi dan Bisnis, 6.

[27] Wibisana, B. H. (2016). Buku panduan menghitung \& mengukur indeks profesionalitas ASN. Jakarta: Badan Kepegawaian Negara.

[28] Winarni, R., \& Ahmad Muftadi, E. S. (2016). Pengaruh Penilaian Prestasi Kerja dan Kompensasi terhadap Kinerja Teknis Kefarmasian Non PNS Instalasi Farmasi RSUD Dr. Hasan Sadikin. Farmasi Klinik Indonesia, 5, 278-287.

[29] Yani, M. (2012). Manajeman Sumber Daya Manusia. Jakarta: Mitra Wacana Media. 